practice within the N.H.S., and reiterated that though the issue had been described as the "pay bed row," in fact it was a fight for the freedom of the individual to make his choice how he wished to spend his money and be treated. The "fight" was about who ran the Health Service, and it was necessary to get away from the press view that it was a pay bed row, he said.

\section{ATTACHMENT OF OVERSEAS DOCTORS}

Dr. Astrey also drew the Council's attention to a C.C.H.M.S. decision (see p. 291) that the attachment scheme for overseas doctors did nothing to safeguard the standards of British medicine, to a large extent had eroded those standards, and should therefore be abolished forthwith. Failing that, an adequate screening process was essential, of a standard not lower than the E.C.F.M.G. examination, before entry to Britain. Dr. Astley said that a report to that effect would be made to the Joint Consultants Committee at its next meeting.

Finally, referring to the consultative document "Democracy in the N.H.S.", he said that the C.C.H.M.S. had made it clear to the J.C.C. that in its view this was a dangerous document. Consultants were concerned that community health councils appeared to be acquiring more power than was originally envisaged.

\section{Organization Committee}

Dr. R. A. A. R. Lawrence, Chairman, Organization Committee, reported that the committee had met during the A.R.M. and had given urgent consideration to the establishment of direct links with medical students under the aegis of the B.M.A. It had been felt that if such links were established they should be at the level of the individual student and not with the student body as a whole. The committee's view was that that might best be approached by way of an extension of the existing associate membership, which was at present open only to medical students in the final three years before qualification. The committee had not considered-at any rate at the present time - that any attempt should be made by the B.M.A. to cater for the political activities of medical students. The question of any ex- tension of the free issue of the B.M.f. together with other matters, would have to be considered. As a first step the committee recommended that approval be given in principle to eligibility for associate membership being extended to all medical students. The Council referred the recommendation to the Finance, Journal, and General Purposes Committees.

\section{Corrections}

\section{Proceedings of Council}

A line was omitted from the second paragraph of the report on the proceedings of the special meeting of Council on $9 \mathrm{July}$ (30 July, p. 200). Mr. Walpole Lewin's statement about the press statement on pay beds issued by Mrs. Borbara
state Statement on pay beds issued by Mrs. Barbara having been agreed with the profession's represenhaving been agreed with the profession's representatives-implying that her Department had succeeded in imposing on the negotiators the fact
that private beds would be phased out of the that private

\section{N.H.S. Doctors' Pay: P.M. Replies}

The heading to the Prime Minister's letter on doctors' remuneration (20 July, p. 210 ) erroneously stated that it was dated 10 July. The letter was, in fact, dated 15 July.

\title{
Central Committee for Hospital Medical Services
}

A meeting of the C.C.H.M.S. was held on 4 July with Dr. C. E. Astley in the chair.

\section{Charing Cross Hospital Dispute}

The Chairman said he was gravely concerned about the situation which had arisen at Charing Cross Hospital and, indeed, at other hospitals in the country, over private beds. It was, he said, an occasion when the C.C.H.M.S. must be seen to be taking very strong action, for even if the dispute were patched up temporarily, it would rear its ugly head again before long.

Dr. D. Stevenson, Secretary, told the Committee that later in the morning he was meeting the Medical Staff Committee at Charing Cross Hospital and would like to have the views of the C.C.H.M.S.

Dr. D. L. Gullick, Under Secretary, outlined the history concerning the provision under the Act for private beds in N.H.S. hospitals, and he suggested several courses of action for consideration by the C.C.H.M.S.

When the N.H.S. had started Mr. Aneurin Bevan, the Minister of Health, had given two Bevan, the Minister of Health, had given two
assurances, the right of the citizen to opt wholly assurances, the right of the citizen to opt wholly
or impart for treatment, and the right of doctors, or impart for treatment, and the right of doctors,
if they chose to do so, to continue to engage in if they chose to do so, to continue to engage in private practice, both within and outside the
Service. The 1946 law passed by that Labour Service. The 1946 law passed by that Labour tion in N.H.S. hospitals, as did the present law -also passed by a Labour Government in 1968. In March 1974 the Secretary of State, Mrs. Barbara Castle, had asked doctors to re-examin this situation, in the light of her party's policy of "phasing out" private practice within the not in agreement with the policy, and having not in agreement with the policy, and having suffered long frustration in its attempts to reform consultant contracts, had agreed to discuss the matter -and others - in the Joint Working Party chaired by the U.
Dr. David Owen, M.P.

Certain groups of workers had now threatened the continuance of private accommodation, and by the use of ultimata would at least inconvenience, or at worst endanger, patients who had entered N.H.S. hospitals in good faith for treatment under a contract based on the law of the land. That action also constituted an attempt to alter by force the contracts of doctors working in the N.H.S., and was yet another example of a small group of people seeking by threats to achieve a politica

Despite early warning given to the Secretary of State by the B.M.A., continued Dr. Gullick, her intervention was belated and had been limited to intervention was belated and had been limited to
simple exhortation. She had declined, though simple exhortation. She had declined, though
she was the responsible Minister to take action to she was the responsible Minister to take action to
support the health authorities who were running support the

He suggested that if the Secretary of State
the failed to intervene consultants should adhere strictly to their notional half-day sessions; restrict all the extra services and facilities which consultants commonly provide voluntarily out side sessional hours; and discontinue non-therapeutic work such as committees, lectures and examinations to non-medical staf, pre-employment medical examinat

All medical and surgical emergencies should have priority at all times, if necessary over have priority
routine work.

\section{ACT:ON TOO WEAK}

Mr. T. M. HenNeBry thought that while Dr. Gullick's statement was reasonable the courses of action proposed were too weak. Something more drastic was required, he said, such as the closure of any hospital involved except for the treatment of emergencies. Dr. M. Sim suggested that the attachment scheme, which he described as a rope fashioned by consultants to hang themselves, must cease forthwith. Some 2,500 overseas doctors had been placed on the temporary Register last year and there were some 1,800 already practising here. Stopping the scheme would not affect patients but it would affect the training and assessment of foreign doctors who could be used to man the Service.
Mr. Alan RHodes supported the suggestion that in any hospital in which action was being taken by the National Union of Public Employees medical staff should withdraw their services except for emergencies. $\mathrm{He}$ also proposed that the profession should withdraw from the Owen Working Party, pointing out that in all her recent utterances the Secretary of State had clearly prejudged its outcome.

Supporting Mr. Rhodes's suggestion of withdrawal from the Owen Working Party, Mr. D. E. Bolt said that so far as action in hospitals was concerned the machinery should be set up to allow the profession to extend action to all N.H.S. hospitals. Professional standards must be defended, and the methods adopted should be those designed to reduce the work load in hospitals to a level for which hospitals were equipped and staffed. While such a step would not be effective immediately it soon would be so.

Mr. R. MYLES GiBSON demanded a definite stand immediately because the issue fundamentally affected the contractual status of the hospital doctor in the N.H.S. The Secretary of State by sympathizing with the aims of the strikers had prejudged the Owen Working Party and the profession would lose credibility if it continued to negotiate with her there.

As to the action to be taken, Mr. Myles Gibson agreed that hospital doctors should take no part in routine work, and deal only with genuine emergency cases in those hospitals affected by the union action. Designated private beds not occupied by private patients and which it was suggested should be filled by N.H.S. patients should not be staffed by N.H.S. doctors.

A suggestion by the Chairman that the treatment only of genuine emergencies should involve all hospitals and not only those affected by the union's action was 